Canadian

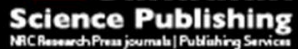

Canadian Journal of Physiology and Pharmacology Revue canadienne de physiologie et pharmacologie

\title{
Beta-sitosterol up-regulated Paraoxonase-1 via Peroxisome Proliferator-Activated Receptor-y in Irradiated Rats
}

\begin{tabular}{|r|l|}
\hline Journal: & Canadian Journal of Physiology and Pharmacology \\
\hline Manuscript ID & cjpp-2016-0397.R1 \\
\hline Manuscript Type: & Article \\
\hline Date Submitted by the Author: & 15-Aug-2016 \\
\hline Complete List of Authors: & $\begin{array}{l}\text { Moustafa, Enas; Egyptian Atomic Energy Authority } \\
\text { Thabet, Noura; Egyptian Atomic Energy Authority, Department of Radiation } \\
\text { Biology }\end{array}$ \\
\hline Keyword: & $\beta$-Sitosterol, Y-radiation, PPAR-Y, PON-1, MDA \\
\hline \multicolumn{2}{|l}{} \\
\hline
\end{tabular}

SCHOLARONE ${ }^{\text {IM }}$

Manuscripts 


\title{
Beta-sitosterol up-regulated Paraoxonase-1 via Peroxisome Proliferator-Activated Receptor- $\gamma$ in Irradiated Rats
}

\author{
Enas Mahmoud Moustafa and Noura Magdy Thabet* \\ Radiation Biology Department, National Centre for Radiation Research and Technology, Atomic \\ Energy Authority, Cairo, Egypt
}

*Corresponding authors: noura_magdy@hotmail.com 


\section{Abstract}

This study was designed to evaluate the effect of Beta-sitosterol (BS) on the of peroxisome proliferator-activated receptor gamma (PPAR- $\gamma$ ) gene expression role in the activity of PON-1 enzyme in oxidative stress status of irradiated rats. Animals were exposed to whole body $\gamma$-radiation single dose $6 \mathrm{~Gy}$ and received $\mathrm{BS}$ dose $\left(40 \mathrm{mg} \cdot(\mathrm{kg} \text { body mass })^{-1} \cdot\right.$ day $^{-1}$, orally). In liver tissue, gene expression of PPAR- $\gamma$ ligand was determined. Oxidative stress marker (malonyldialdehyde, MDA) and antioxidant enzymes activities (Superoxide dismutase; SOD Catalase; CAT, PON-1 and arylesterase; ARE) were assayed in serum and liver tissue. Also, serum lipid profile (Cholesterol, triglycerides; TG, low-density lipoproteins; LDL-c and highdensity lipoproteins; HDL-c) was measured. In irradiated animals received BS, expression of PPAR- $\gamma$ ligand increase significantly associated with increase in PON-1/ARE enzymes activities. Also, the activities of SOD, CAT enzymes and HDL-c levels display elevation. Whereas, significant decrease in MDA content, cholesterol, TG and LDL-c levels were revealed after BS administration. Our findings in this study provides the evidence that, BS have radio-protective effect via regulate the gene expression of PPAR- $\gamma$ cause increase in PON-1 and ARE enzymes activities. This action of BS due to its free radicals scavenging properties, antioxidant effect, lowering of cholesterol and PPAR- $\gamma$ agonist properties.

Keywords: $\beta$-Sitosterol, $\gamma$-radiation, PPAR- $\gamma$, PON-1, MDA 


\section{Introduction}

The exposure of living organisms to ionizing radiation-induce damage, has a lot in common with other metabolic stress and diseases. The underlying mechanism, in most cases, is oxidative stress and metabolic dysfunction that leads to cell injury through damage the major cell structural and functional components, such as proteins, lipids and DNA. It is highly cumulative damage happened by excessive production of reactive oxygen species (ROS) and reactive nitrogen species (RNS). Radiation toxicity symptoms include fatigue, migraines, hypertension, allergic reactions, disorders of the central nervous system, flu-like symptoms, low red and white blood cell counts, in addition to the different types of cancers (Virmani and Diedenhofen 2015).

Peroxisome proliferator activated receptor- $\gamma(\operatorname{PPAR}-\gamma)$ is a ligand-binding transcription factor, which belongs to the nuclear receptor super family, expressed throughout the body ( Bozaykuta et al. 2014). Furthermore, PPAR- $\gamma$ regulates expression of genes involved in lipid metabolism, inflammatory responses, and other biological processes. Also, PPAR- $\gamma$ controls a dipocyte differentiation, glucose metabolism, and lipid homeostasis (Ren et al. 2015). The activity of paraoxonase is regulated by PPAR- $\gamma$ (Khateeb et al. 2012).

Paraoxonase (PON-1), is antioxidant enzyme, belongs to a family of calcium-dependent esterases that includes PON-1, PON-2 and PON-3. These enzymes catalyze the hydrolysis of a broad spectrum of substrates including organophosphates and aryl esters. PON-1 activity has been traditionally measured by employing two different substrates: paraoxon (paraoxonase activity) and phenylacetate (arylesterase activity, ARE) (Romani et al. 2009). PON-1 is mainly synthesized in the liver tissue and secreted into the blood circulation (Yildirim et al. 2012). PON1 has anti-oxidative properties, is closely associated with high-density lipoproteins (HDL), which 
detoxifies lipid peroxides and protect low-density lipoproteins (LDL) from oxidation (Al-Rejaie et al. 2013). Furthermore, PON-1 also decrease the lipid peroxidation caused by the free radicals on the cell membranes and lipoproteins (Yildirim et al. 2012). Furthermore, Guo et al. (2015) found that regulation of PON-1 gene play a protective effect against oxidative stress of liver injury via reduce lipid peroxidation content and enhance superoxide dismutase (SOD) and catalase (CAT) activities. Meanwhile, PON-1 is an important determinant to decrease macrophage oxidative status, to stimulate cholesterol efflux from macrophages, decrease oxidative status, and to confer cytoprotection against apoptosis by up-regulating macrophage scavenger receptor. Thus, the decreased in PON-1 activity release from the liver would lead to deleterious effect (Khateeb et al. 2012).

Adhering to the hypothesis that the exposure of hepatocytes to free fatty acids in the context of dyslipidemia, resulting in increased ROS production and mitochondrial damage, is balanced by the presence of antioxidant substances, circulating levels of cytochrome c, triglycerides and unconjugated bilirubin should to be explored (Tarantino et al. 2011). Phytosterols are naturally compounds bear a resemblance to cholesterol both in structure and biological function. They regulate membrane fluidity and permeability in addition to membraneassociated metabolic processes (Trautwein and Demonty 2007). However, phytosterols have several potential mechanisms which include decrease the levels of proinflammatory cytokines, modulation of signaling pathways, growth arrest, activation of cellular stress responses, reduction of cholesterol synthesis with suppression of 3-hydroxy-3-methyl-glutaryl-CoA reductase (HMG-CoA reductase) and promotion of reverse cholesterol transport (Houston 2012). The biological majority significant phytosterols are sitosterol, campesterol, stigmasterol and brassicasterol (Trautwein and Demonty 2007). $\beta$-Sitosterol (BS) has been display raises in 
enzymatic and non-enzymatic antioxidant in cells making it effective as anti-diabetic, neuroprotective and chemoprotective agent (Saeidnia et al. 2014). Moreover, $\beta$-sitosterol increase the antioxidant activity, altering the gene expressions, inducing apoptosis, and inhibiting angiogenesis and metastasis, but extensive researchs are highly recommended (Bin Sayeed and Ameen 2015).

This study aimed to gain insight into the role of $\beta$-Sitosterol on the link between PPAR- $\gamma$ expression and activity of PON-1 enzyme in oxidative stress status induced by radiation. This goal was investigated by assay of PPAR- $\gamma$, PON-1, ARE, SOD, CAT, MDA and lipid profile (Cholesterol, triglycerides; TG, LDL-c and HDL-c) in rats serum and liver.

\section{Materials and methods:-}

Materials: $\beta$-Sitosterol obtained from (C) SOURCE NATURALS, INC. All chemicals used in these study were purchased from Sigma (St. Louis, MO, U.S.A.).

Experimental Animals: In this study, six weeks old male albino rats weighed 120-150 gm were used. The rats were purchased from the breeding unit of Egyptian Holding Company for Biological Products and Vaccines. The animals were housed in standard cages; food and water were provided ad libitum. Animals experimentation were consistent with the guidelines of Ethics by the Guide for the Care and Use of Laboratory Animals (National Research Council 1996) in accordance with the recommendations for the proper care and use of laboratory animals approved by animal care committee of the National Centre for Radiation Research and Technology (NCRRT), Cairo, Egypt. 
Irradiation: The irradiation of whole body gamma irradiation was performed at the NCRRT (Cairo, Egypt) using Canadian gamma cell-40 $\left({ }^{137} \mathrm{Cesium}\right)$ at a dose rate $0.49 \mathrm{~Gy} \mathrm{~min}^{-1}$.

Experimental setup: Rats were divided into 4 groups (6 rats/group). Control group (C): rats were received oral saline $(0.5 \mathrm{ml} /$ day $)$ for 10 days; $\beta$-sitosterol group $(\mathrm{BS})$ : rats received BS dose (40 $\left.\mathrm{mg} \cdot(\mathrm{kg} \text { body mass })^{-1} \cdot \mathrm{day}^{-1}\right)$ orally for 10 consecutive days (Ganapathy et al. 2014); Irradiated group (R): rats were received $0.5 \mathrm{ml}$ saline orally for 10 days and exposed to single dose 6 Gy of $\gamma$-radiation on the $9^{\text {th }}$ day of experiment; BS+R group: rats received BS and exposed to $\gamma$-radiation.

At the end of the experiments, after an overnight fast, rats were anesthetized with ether and then sacrificed. Blood samples were taken just prior to dissection from the venous plexus behind the orbit in a sterile centrifuge tube and allow to clot overnight $\left(4^{\circ} \mathrm{C}\right)$ then serum was separated following centrifugation $(1500 / \mathrm{min}$ for $30 \mathrm{~min})$. Liver was directly separated after sacrificing; a known weight of the liver tissue was homogenized in buffer solution using homogenizer then the cell debris was removed by centrifugation at $3000 \mathrm{rpm}$ for $10 \mathrm{~min}$. The homogenates supernatant and serum were used for the estimation of the following biochemical analysis.

\section{Detection of PPAR- $\gamma$ gene expression:}

RNA extraction and $c D N A$ synthesis: from liver tissue homogenates, total RNA was isolated using RNeasy Purification Reagent (Qiagen, Valencia, CA) in accordance with manufacturer's instruction. The purity (A260/A280 ratio) and the concentration of RNA were obtained using spectrophotometry (GeneQuant 1300, Uppsala, Sweden). gel electrophoresis was used to 
confirm RNA quality. First-strand cDNA was synthesized from $4 \mu \mathrm{g}$ of total RNA using an Oligo (dT)12-18 primer and Superscript ${ }^{\mathrm{TM}}$ II RNase Reverse Transcriptase, This mixture was incubated at $42^{\circ} \mathrm{C}$ for $1 \mathrm{~h}$, the kit was supplied by SuperScript Choice System (Life Technologies, Breda, the Netherlands). Real-time quantitative polymerase chain reaction (PCR): The genes expression of PPAR- $\gamma$ was examined using real-time PCR with the primers (Forward 5' GCGGAGATCTCCAGTGATATC3' and Reverse 5' TCAGCGACTGGGACTTTTCT3'). Real-time PCR (RT-PCR) amplification was carried out using $10 \mu \mathrm{L}$ amplification mixtures containing Power SYBR Green PCR Master Mix (Applied Biosystems, Foster City, CA USA), equivalent to $8 \mathrm{ng}$ of reverse-transcribed RNA and $300 \mathrm{nM}$ primers. Reactions were carried out in the ABI 7500 quantitative PCR (qPCR) (Applied Biosystems) or Eppendorf Realplex instrument. PCR reactions were conducted as follows: first cycle of $10 \mathrm{~min}$ at $95^{\circ} \mathrm{C}$ was followed by 40 cycles of $15 \mathrm{~s}$ at $94^{\circ} \mathrm{C}, 20 \mathrm{~s}$ at $55^{\circ} \mathrm{C}$, and $20 \mathrm{~s}$ at $68^{\circ} \mathrm{C}$. Data were analyzed with the ABI Prism sequence detection system software and quantified using the v1.7 Sequence Detection Software from PE Biosystems (Foster City, CA). Relative expression of studied genes was calculated using the comparative threshold cycle method. All values were normalized to the GAPDH genes (Forward: 5'- CTCCCATTCTTCCACCTTTG-3' and Reverse: 5'CTTGCTCTCAGTATCCTTGC-3') (Livak and Schmittgen 2001).

Biochemical Assay: In serum and liver tissue, PON-1 and ARE activities were measured spectrophotometrically according to the method described by Gan et al. (1990). PON-1 activity was determined by using $1.0 \mathrm{mM}$ paraoxon as substrate in $50 \mathrm{mM}$ glycine/ $\mathrm{NaOH}(\mathrm{pH} 8.0), 1$ $\mathrm{mM} \mathrm{CaCl}_{2}$, and $1 \mathrm{M} \mathrm{NaCl}$. The generation of $p$-nitrophenol at $25^{\circ} \mathrm{C}$ was monitored at $412 \mathrm{~nm}$ in a continuously recording spectrophotometer. Enzyme activity was calculated with a molar extinction coefficient of $18,290 \mathrm{M}^{-1} \mathrm{~cm}^{-1}$. One unit of PON activity produced $1 \mathrm{nM}$ of $p$ - 
nitrophenol per minute. ARE activity was measured by using as substrate phenyl acetate in 20 Mm Tris- $\mathrm{HCl}\left(\mathrm{pH}\right.$ 8.0) containing $1 \mathrm{mM} \mathrm{CaCl}_{2}$. The rate of hydrolysis was determined spectrophotometrically at $270 \mathrm{~nm}$. Enzyme activity was calculated with a molar extinction coefficient of $1,310 \mathrm{M}^{-1} \mathrm{~cm}^{-1}$. One unit of ARE activity corresponded to $1 \mu \mathrm{M}$ of phenyl acetate hydrolyzed per minute. Oxidative stress marker, lipid peroxidation product, malonaldahydy (MDA), was measured by thiobarbituric acid assay, which is based on MDA reaction with thiobarbituric acid forming thiobarbituric acid reactive substances (TBARS), a pink colored complex exhibiting a maximum absorption at $532 \mathrm{~nm}$ (Yoshioka et al. 1979). The antioxidant enzymes SOD and CAT activities were assayed via the method of Kakkar et al. 1984 and Bergmeyer et al. 1986 respectively. The activity of SOD determined based on the inhibition of superoxide ions generated by phenazine methosulfate that converts nitroblue tetrazolium (NBT) to NBT-diformazan, which absorbs light at $560 \mathrm{~nm}$. The SOD activity was defined as the amount of enzyme required to give $50 \%$ inhibition of NBT reduction and expressed as units/ mg protein. The CAT activity was assay based on the disappearance of peroxide is followed spectrophotometrically at 240nm. One unit of the enzyme is expressed as m moles of $\mathrm{H}_{2} \mathrm{O}_{2}$ utilized per minute per g protein. In serum, lipid profile (Cholesterol, TG, LDL-c and HDL-c) were determined. Whereas, Cholesterol, TG and HDL-c measured by ELISA kit supplied by R and D System USA after following the manufacturer's instruction, and LDL-c was calculated by the Friedewald equation in those with TG levels $4.52 \mathrm{mmol} / \mathrm{L}$ (Friedewald et al. 1972).

Statistical Analysis: Data subjected to statistical analysis and performed tests of significance using the statistical package SPSS (Statistical Program for Social Science) version 15.0 by applying one-way ANOVA test followed by post hoc test for multiple comparisons. All data are 
expressed as mean of 6 values \pm S.E and difference between means are considered significant at $P<0.05$.

\section{Results:}

\section{PPAR- $\gamma$ Gene Expression}

The results of BS group revealed non-significant change in PPAR- $\gamma$ mRNA expression compared with control. But, $\mathrm{R}$ group display significant $(P<0.05)$ reduction in PPAR- $\gamma$ mRNA gene expression when compared to control. On the other hand, administration of BS showed significant $(P<0.05)$ improvement in PPAR- $\gamma$ mRNA expression of $\mathrm{BS}+\mathrm{R}$ group as compared with R-group (Figure 1).

\section{PON-1 and ARE enzymes activities}

In BS group, the data showed non-significant change in the PON activity when compared to control. In R group, the experimental data display that the PON activity was decline significantly $(P<0.05)$ when compared to control group in both serum and liver. On the other hand, the administration of BS significantly $(P<0.05)$ enhanced the activities of PON in both serum and liver of BS $+\mathrm{R}$ group as compared with R group (Figure 2).

In the BS group the results revealed normal in ARE activity as control. In R group, the data observed significant $(P<0.05)$ decline in ARE activity in both serum and liver when compared to control group. The oral administration of $\mathrm{BS}$ in $\mathrm{BS}+\mathrm{R}$ group, revealed significant $(P<0.05)$ enhanced in the activities of both serum and liver ARE compares with R-group (Figure 3). 


\section{MDA}

Serum and liver levels of MDA in BS group was similar with control level. The oxidative stress marker MDA was significantly $(P<0.05)$ increase in serum and liver of irradiated rats compared to control group. Treatment with BS display significant decrease in oxidative stress marker MDA levels in serum and liver of BS+R group as compared to R group (Figure 4).

\section{SOD and CAT activities}

Activity of SOD in BS group revealed non-significant compared to control group. The results revealed hazard effect of $\gamma$-radiation on antioxidant enzyme manifested by significant $(P<0.05)$ decrease of serum and liver SOD activity in R-group as compared with control group. Administration of BS showed significant increase in serum and liver SOD activity in BS+R group as compared to R-group (Figure 5).

There is non-significant change in CAT activity in BS-group compared to control group. In R-group, the data revealed significant $(P<0.05)$ decrease in CAT activity as compared with control group (Figure 6). Otherwise, the oral administration of BS to irradiated rats significantly $(P<0.05)$ increase CAT activity in serum and liver when compared to R group (Figure 6).

\section{Lipid Profile}

Data in table (1) represented the levels of lipid profile in serum of BS group, the results revealed non-significant change compared to control group. In $\mathrm{R}$ group, the data display significant $(P<0.05)$ decreased in HDL-C accompanied with significant elevated in Cholesterol, TG and LDL levels when compared to control group (Table 1). Meanwhile, treatment with BS in 
BS $+\mathrm{R}$ group showed significant $(P<0.05)$ improvement in serum levels of lipid profile compared to R group (Table 1).

\section{Discussion:-}

Ionizing radiation exposure is environmental contaminants that may pose long-term health risks. Unfortunately, the consequent implementation of preventive measures was generally delayed, causing important negative effects on the exposed populations.

One of the most important target attacks by $\gamma$-radiation is PPAR- $\gamma$. The decrease observed in gene expression of PPAR- $\gamma$, in the present study, might be attributed to $\gamma$-radiation induces DNA injury via ROS directly or indirectly (Huang et al. 2015). Our results supported with Linard et al. (2008) who found that, irradiation with 10 Gy induced a significant decrease in PPAR $-\gamma$ mRNA levels. PPAR- $\gamma$ is important factors in the regulation of PON-1 and in counteracting oxidative stress (Camps et al. 2012). It was observed that, in serum and hepatic tissue of present study, a significant decrease in PON-1 and ARE activities in irradiated rats. This might probably attributed to Khateeb et al. (2012) who found that, under pathological conditions when hepatocytes exposed to ROS remarkably increase observed in urokinase-type plasminogen activator ( $\mathrm{UPA}$ ) bound to uPA receptor ( $\mathrm{UPAR}$ ), activates mitogen-activated protein kinase kinase, which then translocate to the nucleus, interacts with PPAR- $\gamma$, and induces export of the nuclear PPAR- $\gamma$ to the cytosol. At the end, PON-1 gene transcription and activity is suppressed. In the present study, the possible changes occur in PPAR- $\gamma$ gene expression and accordingly PON-1 activity could be describe the significant increase in oxidative stress marker (MDA) concomitant with a significant decrease activity of the antioxidant enzymes (SOD and CAT) and risk disrupts in lipid profile of irradiated rats. Whereas, several studies have suggested 
that, the decrease in PON-1 activity was associated with an increase in oxidative stress and disturbance in lipid profile. In these studies, PON-1 activity significantly decreased in acute pancreatitis with a positive correlation to the serum HDL level, while a significant increase in the oxidative stress marker, MDA (Unal et al. 2005). Also, Guo et al. (2015) found that, PON-1 play a protective effect against oxidative stress by enhance SOD and CAT activities. Furthermore, low PON-1 activity may contribute to increase the atherosclerosis found in diabetes (type-1) by reducing the ability of HDL to retard LDL oxidation (Mackness et al. 2002). Meanwhile, as PON-1 is an HDL-associated enzyme, reduced HDL levels could result in reduced serum PON-1 activity (Aksoy et al. 2009).

This study aimed to gain insight into the role of $\beta$-Sitosterol on this link in oxidative stress status. From our finding, administration of $\beta$-sitosterol display improvement in oxidative stress status in the present study. This could be attributed to BS possessed as a potential PPAR- $\gamma$ ligand. Whereas Lazim et al. (2015) reported that BS displayed expression of luciferase enzyme which has the ability to express the genes, indicating their binding potential to PPAR- $\gamma$ at certain concentrations. Also, the chemical structure of BS has the capability to bind to PPAR- $\gamma$ similar to thiazolidinedione, which is PPAR- $\gamma$ agonist (Lazim et al. 2015). Furthermore our data agreement with Nencu et al. (2015) who found that, the sterols can activate PPAR- $\gamma$ receptors to reduce the pathological elevated blood glucose found in diabetes mellitus. According to, Khateeb et al. (2012) who demonstrated that PON-1 gene expression and activity in hepatocytes is regulated by PPAR- $\gamma$. Sequentially, this could explain the improvement observed in PON and ARE activities after administration of BS and consecutively in oxidative stress. In addition to, the ameliorative action of BS on lipid profile as shown in the present study might be related to the inhibition of intestinal cholesterol absorption by BS. This agreement with Trautwein and 
Demonty (2007) who reported that $\beta$-sitosterol, has been shown in many studies safe and effective in lowering plasma total and LDL-cholesterol concentrations due to its action as inhibitors of cholesterol absorption. Furthermore, Gupta et al. (2011) demonstrate that BS increase the antioxidant levels of SOD and CAT, with a concomitant decrease in MDA.

The above finding agree with Berger et al. (2004) who reported that plant sterols, in ester or free form, in reasonable doses (0.8-1.0 $\mathrm{g}$ of equivalents per day) and in various vehicles including natural sources, and as part of a healthy diet and lifestyle, are important dietary components for lowering LDL cholesterol and maintaining good heart health. In addition to their cholesterol lowering properties, plant sterols possess anti-inflammatory, anti-atherogenicity, and anti-oxidation activities, and should thus be of clinical importance, even for those individuals without elevated LDL cholesterol. Furthermore, there is emerging evidence suggesting that particularly plant sterols may have beneficial anti-cancer effects against the development of different types of cancers by reduced the incidence of tumors, slowed down cell proliferation and/or lowered the number of metastases (Trautwein and Demonty 2007). Due to these completive properties it has been proposed to use in nonalcoholic fatty liver disease (NAFLD) patients (Tarantino 2007).

Based on the results obtained in the current study it could be concluded that, $\beta$-sitosterol up-regulate PON-1 and ARE enzymes activities via stimulating PPAR- $\gamma$ mRNA expression. Subsequently, this effect decrease oxidative stress marker, increase antioxidant enzyme activity and ameliorate the balance in lipid profile. We recommended that, a diet supplemented with natural $\beta$-sitosterol should be advised to avoid risk radiation expose inducing oxidative stress due 
to its free radicals scavenging properties, antioxidant effect, lowering of cholesterol and PPAR- $\gamma$ agonist properties

Conflict of interest: The authors declare that they have no conflict of interest.

Ethical approval: All applicable international, national, and/or institutional guidelines for the care and use of animals followed. All the experiments conducted under national research centre guidelines for the use and care of laboratory animals and approved by an independent ethics committee of the NCRRT.

\section{References:}

Aksoy, H., Aksoy, A. N., Ozkan, A., and Polat, H. 2009. Serum Lipid Profile, Oxidative Status, and Paraoxonase 1 Activity in Hyperemesis Gravidarum. J. Clin. Lab. Anal. 23: 105-109.

Al-Rejaie, S. S., Aleisa, A. M., Sayed-Ahmed, M. M., AL-Shabanah, O. A., Abuohashish, H. M., Ahmed, M. M., Al-Hosaini, Kh. A., and Hafez, M. M. 2013. Protective effect of rutin on the antioxidant genes expression in hypercholestrolemic male Westar rat. BMC Complement. Altern. Med. 13: 136-145.

Berger, A., Jones, P. JH., and Abumweis, S. S. 2004. Plant sterols: factors affecting their efficacy and safety as functional food ingredients. Lipids in Health and Disease, 3:5-24.

Bergmeyer, H. U., Bergmeyer, J., and Grabl, M. 1986. In Enzymes 1: oxidoreductases, transferases, In: methods of enzymatic analysis, $3^{\text {rd }}$ Edition, VCH Verlagsgesellschaft, P.O. Box 1260/1280, D-6940 Weinheim (Federal Republic of Germany), USA and Canada: VCH Publishers, 303 N.W 12 ${ }^{\text {th }}$ Avenue, Deerfield Beach FL 33442-1705 (USA). 
Bin Sayeed, M. S., and Ameen, S. S. 2015. Beta-Sitosterol: a promising but orphan nutraceutical to fight against cancer. Nutr. Cancer. 67(8): 1214-1220.

Bozaykuta, P., Karademira, B., Yazgana, B., Sozena, E., Siowb, R. C. M., Mannb, G. E., and Ozera, N K. 2014. Effects of vitamin E on peroxisome proliferator-activated receptor $\gamma$ and nuclear factor-erythroid 2-related factor 2 in hypercholesterolemia-induced atherosclerosis. Free Radic. Biol. Med.70: 174-181.

Camps, J., García-Heredia, A., Rull, A., Alonso-Villaverde, C., Aragonés, G., Beltrán-Debòn, R., Rodríguez-Gallego, E., and Joven, J. 2012. Review Article: PPARs in Regulation of Paraoxonases: Control of Oxidative Stress and Inflammation Pathways. PPAR Res. 2012: Article ID 616371(10 pages).

Friedewald, W. T., Levy, R. I., and Fredrickson, D. S. 1972. Estimation of the concentration of low-density lipoprotein cholesterol in plasma, without use of the preparative ultracentrifuge. Clin. Chem. 18: 499-502.

Gan, K. N, Smolen, A., Eckerson, H. W., and La Du, B. N. 1990. Purification of Human Serum Paraoxonase/Arylesterase: Evidence for One Esterase Catalyzing Both Activities. Drug Metab. Dispos. 19 (1): 100-106.

Ganapathy, P., Rajadurai, M., and Ashokumar, 2014. Effect of $\beta$-Sitosterol on Cardiac Troponins, Marker Enzymes and Biochemical Parameters in Isoproterenol-Induced Myocardial Infarction. J. Acad. Ind. Res.3 (5): 209-214. 
Guo, R., Chen, L., Lian, J., Wu, B., Hong, G., Ge, Y., Liu, Y., Qiu, Q., and Lu, Z. 2015.The protective effect of regulation of paraoxonase 1 gene on liver oxidative stress injury induced by dichlorvos poisoning in mice. Zhonghua Wei Zhong Bing Ji Jiu Yi Xue. 27(4): 285-90.

Gupta, R., Sharma, A. K., Dobhal, M. P., Sharma, M. C., and Gupta, R. S. 2011. Original Article: Antidiabetic and antioxidant potential of $\beta$-sitosterol in streptozotocin-induced experimental hyperglycemia. J. Diabetes, 3: 29-37.

Houston, M. 2012. The Role of Nutraceutical Supplements in the Treatment of Dyslipidemia, J. Clin. Hypertens. 14(2): 121-132.

Huang, B., Guang, M., Ye, J., Gong, P., and Tang, H. 2015. Effect of Increasing Doses of $\gamma$ Radiation on Bone Marrow Stromal Cells Grown on Smooth and Rough Titanium Surfaces. Stem Cells International, 2015: Article ID 359416 (11 pages).

Kakkar, P., Das, B., and Viswanatham, P. N. 1984. A modified spectrophotometric assay of super oxide dismutase. Indian J. Biochem. Biophys. 21: 130-132.

Khateeb, J., Kiyan, Y., Aviram, M., Tkachuk, S., Dumler, I., and Fuhrman, B. 2012. UrokinaseType Plasminogen Activator Downregulates Paraoxonase 1 Expression in Hepatocytes by Stimulating Peroxisome Proliferator-Activated Receptor- $\gamma$ Nuclear Export. Arterioscler. Thromb. Vasc. Biol. 32: 449-458. 
Lazim, N. H. M., Asari, A., Mohamad, F., Muhammad, T. T. S., Ismail, N., Taib, M., Aziz, A., and Mohamad, H. 2015. Phenyl ethanone and sterols from Acanthaster planci as potential PPAR-ligand. J. Chem. Pharm. Res. 7(9): 121-126.

Linard, C., Grémy, O., and Benderitter, M. 2008. Reduction of Peroxisome ProliferationActivated Receptor $\gamma$ Expression by $\gamma$-Irradiation as a Mechanism Contributing to Inflammatory Response in Rat Colon: Modulation by the 5-Aminosalicylic Acid Agonist. J. Pharmacol. Exp. Ther. 324: 911-920.

Livak, K. J., and Schmittgen, T. D. 2001. Analysis of Relative Gene Expression Data Using Real-Time Quantitative PCR and the 22DDCT. Methods, 25: 402-408.

Mackness, B., Durrington, P. N., Boulton, A. J. M., Hine, D., and Mackness, M. I. 2002. Serum paraoxonase activity in patients with type 1 diabetes compared to healthy controls. Eur. J. Clin. Invest. 32(4): 259-264.

Nencu, I., Vlase, L., Istudor, V., and Mircea, T. 2015. Preliminary Research Regarding Urtica Urens L. and Urtica Dioica L. FARMACIA. 63(5): 710-715.

Ren, P., Zhang, Y., Huang, Y., Yang, Y., and Jiang, M. 2015. Functions of Peroxisome Proliferator-Activated Receptor Gamma (PPAR $\gamma$ ) in Gynecologic Disorders. Clin. Med. Insights Oncol. 9: 43-49.

Romani, R., De Medio, G. E., di Tullio, S., Lapalombella, R., Pirisinu, I., Margonato, V., Veicsteina, A., Marini, M., and Rosi, G. 2009. Modulation of paraoxonase 1 and 3 expression after moderate exercise training in the rat. J. Lipid Res. 50(10): 2036-2045. 
Saeidnia, S., Manayi, A., Gohari, A. R., and Abdollahi, M. 2014. The Story of Beta-sitosterol- A Review. Eur. J. Med. Plants, 4(5): 590-609.

Tarantino, G. 2007. Should nonalcoholic fatty liver disease be regarded as a hepatic illness only?. World J Gastroenterol. 13(35):4669-4672.

Tarantino, G., Colao, A., Capone, D., Conca, P., Tarantino, M., Grimaldi, E., Chianese, D., Finelli, C., Contaldo, F., Scopacasa, F., and Savastano, S. 2011. Circulating levels of cytochrome C, gamma-glutamyl transferase, triglycerides and unconjugated bilirubin in overweight/obese patients with non-alcoholic fatty liver disease. J. Biol. Regul. Homeost. Agents, 25(1): 47-56.

Trautwein, E. A., and Demonty, I. 2007. Phytosterols: natural compounds with established and emerging health benefits. Ocl-Oleagineux Corps. Gras. Lipides, 14(5): 259-266.

Unal, E., Uzun, H., Kusaslan, R., Dogan, M., Genc, H., Gunes, P., and Titiz, I. 2005. Serum paraoxonase (a high-density lipoprotein-associated lipophilic antioxidant) activity and lipid profile in experimental acute pancreatitis. Pancreas, 31(1): 84-87.

Virmani, A., and Diedenhofen, A. 2015. The Possible Mechanisms Involved in the Protection Strategies against Radiation-Induced Cellular Damage by Carnitines. Int. J. Clin. Med.6: $71-80$.

Yildirim, S., Kisa, F., Karadeniz, A., Yildirim, A., Karakoc, A., Can, I., Kara, A., and Simsek, N. 2012. Effects of pomegranate seed extract on liver paraoxonase and bcl-x L activities in rats treated with cisplatin. J. Med. Plants Res. 6(12): 2317-2323. 
Yoshioka, T., Kawada, K., Shimada, T., and Mori, M. 1979. Lipid peroxidation in maternal and cord blood and protective mechanism against activated-oxygen toxicity in the blood. Am. J. Obstet. Gynecol. 135: 372-376. 
Table 1: Effect of BS on lipid profile in serum of irradiated rats. 
Figure 1: Effect of BS on PPAR- $\gamma$ mRNA expression in liver tissue of irradiated rats. Each value represents the mean $\pm \mathrm{SD}(n=6)$. Values with different superscripts are significantly different, at $P \leq 0.05$ and values with same superscripts not-significantly different, at $P \leq 0.05$.

Figure 2: Effect of BS on PON activity in serum (A) and liver tissue (B) of irradiated rats. Each value represents the mean $\pm \mathrm{SD}(n=6)$. Values with different superscripts are significantly different, at $P \leq 0.05$ and values with same superscripts not-significantly different, at $P \leq 0.05$.

Figure 3: Effect of BS on ARE activity in serum (A) and liver tissue (B) of irradiated rats. Each value represents the mean $\pm \mathrm{SD}(n=6)$. Values with different superscripts are significantly different, at $P \leq 0.05$ and values with same superscripts not-significantly different, at $P \leq 0.05$.

Figure 4: Effect of BS on MDA levels in serum (A) and liver tissue (B) of irradiated rats. Each value represents the mean $\pm \mathrm{SD}(n=6)$. Values with different superscripts are significantly different, at $P \leq 0.05$ and values with same superscripts not-significantly different, at $P \leq 0.05$.

Figure 5: Effect of BS on SOD activity in serum (A) and liver tissue (B) of irradiated rats. Each value represents the mean $\pm \mathrm{SD}(n=6)$. Values with different superscripts are significantly different, at $P \leq 0.05$ and values with same superscripts not-significantly different, at $P \leq 0.05$.

Figure 6: Effect of BS on CAT activity in serum (A) and liver tissue (B) of irradiated rats. Each value represents the mean $\pm \mathrm{SD}(n=6)$. Values with different superscripts are significantly different, at $P \leq 0.05$ and values with same superscripts not-significantly different, at $P \leq 0.05$. 
Table 1: Effect of BS on lipid profile in serum of irradiated rats.

\begin{tabular}{lcccc}
\cline { 2 - 4 } & \multicolumn{4}{c}{ Animal groups } \\
\cline { 2 - 5 } & Control & BS & $\mathbf{R}$ & BS+R \\
\hline Cholesterol $(\mathrm{mg} / \mathrm{dl})$ & $102.68 \pm 5.07^{\mathrm{a}}$ & $99.24 \pm 5.46^{\mathrm{a}}$ & $138.66 \pm 13.29^{\mathrm{b}}$ & $108.02 \pm 10.49^{\mathrm{a}}$ \\
\hline TG $(\mathrm{mg} / \mathrm{dl})$ & $83.29 \pm 4.24^{\mathrm{a}}$ & $69.99 \pm 4.39^{\mathrm{a}}$ & $159.79 \pm 17.53^{\mathrm{b}}$ & $137.12 \pm 12.87^{\mathrm{c}}$ \\
\hline $\mathbf{L D L}-\mathbf{c}(\mathrm{mg} / \mathrm{dl})$ & $61.57 \pm 3.35^{\mathrm{a}}$ & $59.22 \pm 3.29^{\mathrm{ac}}$ & $96.39 \pm 9.70^{\mathrm{b}}$ & $54.39 \pm 5.04^{\mathrm{c}}$ \\
\hline HDL-c $(\mathrm{mg} / \mathrm{dl})$ & $24.92 \pm 1.35^{\mathrm{a}}$ & $26.04 \pm 1.51^{\mathrm{a}}$ & $18.96 \pm 6.94^{\mathrm{b}}$ & $24.19 \pm 2.48^{\mathrm{a}}$ \\
\hline $\begin{array}{l}\text { Each value represents the mean } \pm \text { SD }(n=6) . \text { Values with different superscripts are significantly } \\
\text { different, at } P \leq 0.05 \text { and values with same superscripts not-significantly different, at } P \leq 0.05 .\end{array}$
\end{tabular}




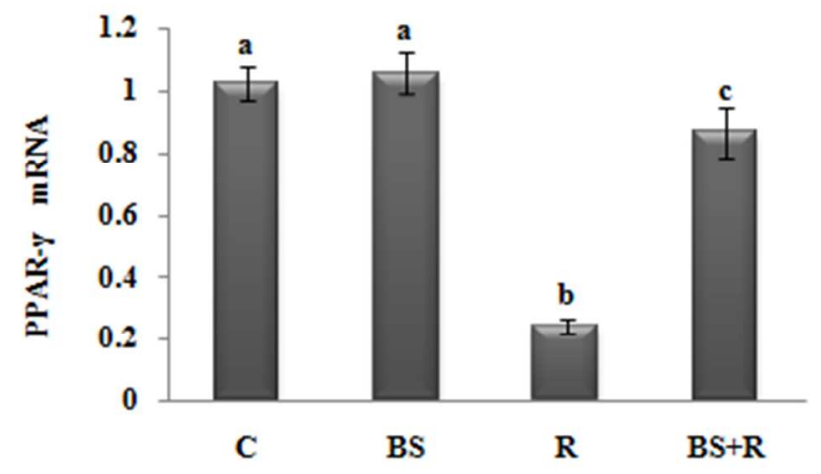

Figure 1 

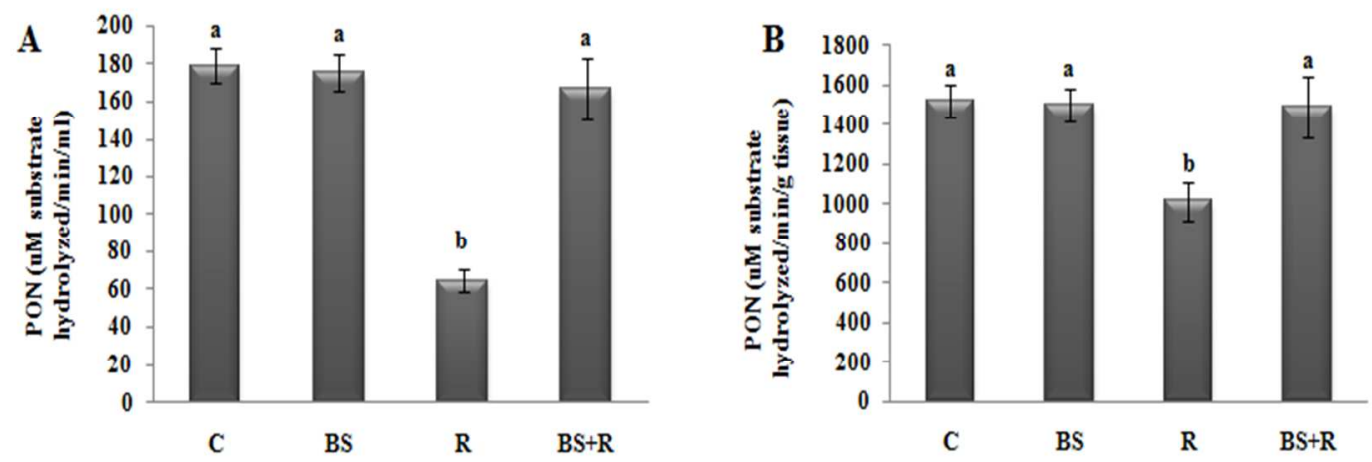

Figure 2 

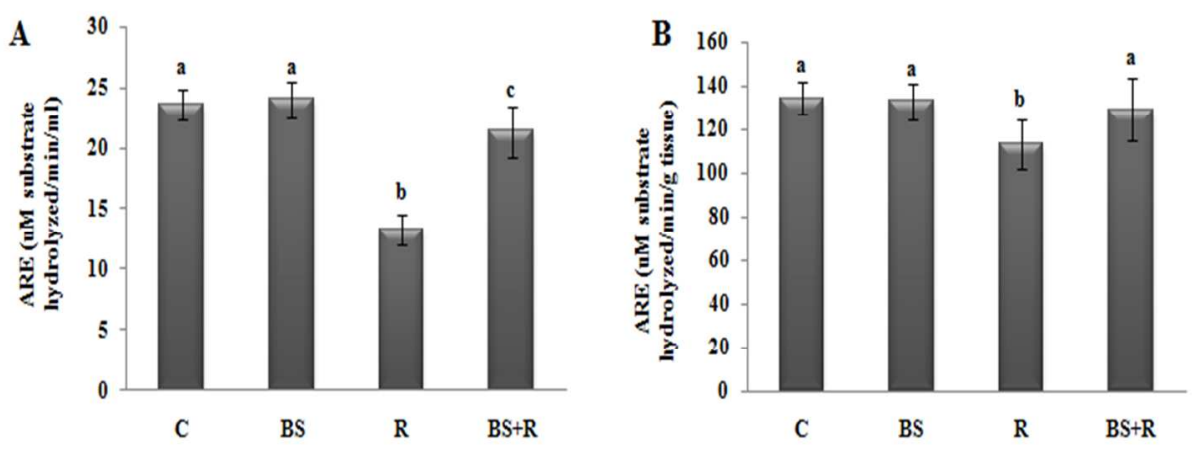

Figure 3 

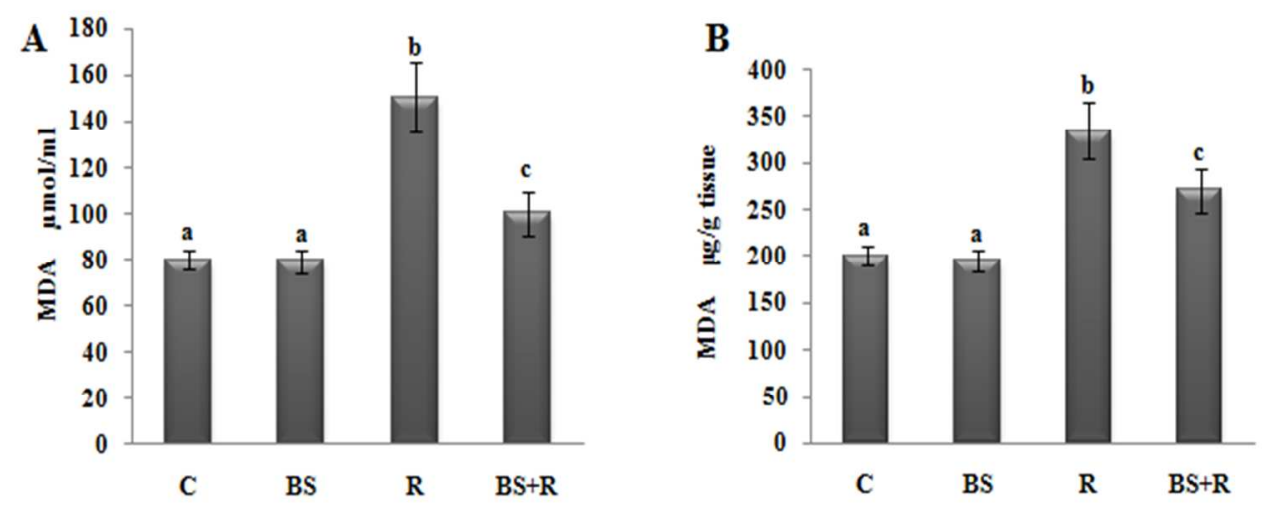

Figure 4 

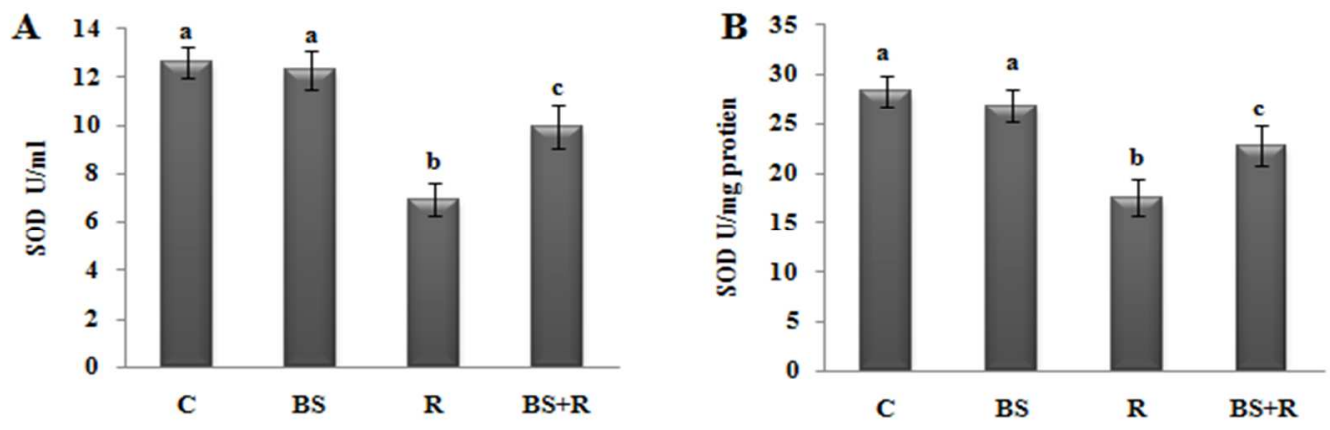

Figure 5 

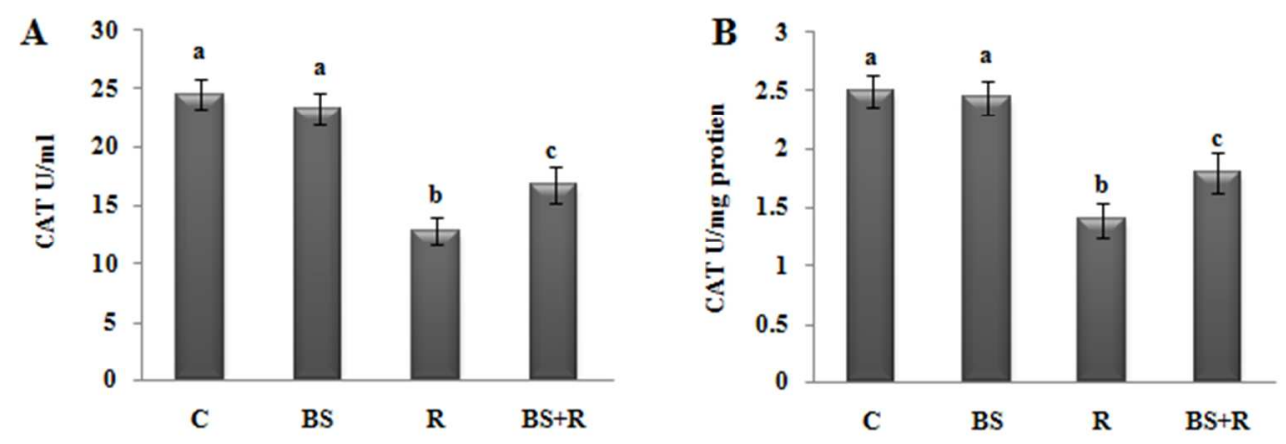

Figure 6 